Article

\title{
There Has Been No Remorse over It: A Narrative Inquiry Exploring Enslaved Ancestral Roots through a Critical Family History Project
}

\author{
Vicki Mokuria ${ }^{1, *(\mathbb{C}}$, Alexia Williams ${ }^{2}$ and William Page ${ }^{3}$ \\ 1 Education Studies, Stephen F. Austin State University, Nacogdoches, TX 75962, USA \\ 2 College of Liberal Arts, Texas A\&M University, College Station, TX 77843, USA; alexia22@tamu.edu \\ 3 University Library, Texas A\&M University, College Station, TX 77843, USA; w-page@library.tamu.edu \\ * Correspondence: vgmokuria@gmail.com or Vicki.Mokuria@sfasu.edu; Tel.: +1-214-282-8033
}

Received: 2 February 2020; Accepted: 9 March 2020; Published: 12 March 2020

check for updates

\begin{abstract}
This paper explores the benefits and value of college students' conducting critical family history (CFH) projects, which may serve as curricular material to expand students' understanding of complex aspects of history and immigration. This article unpacks how one student came to see herself and others from a deeper perspective, particularly through the lens of someone who chose to continue digging into her enslaved ancestors' roots. Using narrative inquiry, a college instructor and former student collaboratively reflect on the lessons learned from using a CFH project in a college-level class primarily for preservice teachers. A unique aspect of this paper is that it gives voice to a former student in the class, which provides a way of seeing the complexities and dehumanizing components of the lives of enslaved Africans in the U.S.- often sanitized out of history books. In addition, a university librarian suggests approaches to genealogical research, by focusing more on the lived experiences of ancestors that go beyond dates and locations. The perspectives from both a former student and the college instructor add multiple dimensions on lessons learned from a critical family history project, which uses students' family histories as funds of knowledge as the primary curriculum.
\end{abstract}

Keywords: critical family history; narrative inquiry; preservice teacher education; African-American history; Soka educational philosophy

\section{Introduction}

This article was primarily a collaborative effort by a teacher educator whose former student (pseudonym of "Alicia") sought to further research her ancestral roots after conducting a Critical Family History ( $\mathrm{CFH}$ ) project, as part of a multicultural education class assignment. One of the university's librarians, the third co-author, who has a keen interest in genealogy, provided support and guidance to students. He mainly emphasized the primacy of family stories and provided examples in such a way as to motivate students to seek out stories from family elders, while also providing concrete resources. In addition, the librarian gave several examples, like the one below, to illustrate how historical data can be tied with one's family's history, if few stories are available:

My great-great grandmother, Elizabeth Robinson Reese, didn't leave any diaries or letters. Census records indicate that for 20 years, she was either pregnant, or had a child under the age of two years, or both. Social histories suggest she gave birth at home, most likely attended by a relative or a neighbor, but without a doctor. She had a hard life. She had to make her family's clothes [and based on historical research] it took a week to make one pair of socks. This kind of information helps researchers grasp how family roles have changed. 
Since historical data through the census may not have been accessible for all students, family stories are also important. It is essential to note that while family stories may include embellishments and are subject to fallible memory, such stories can serve as significant starting points and springboards for a deeper study into social-political-historical research linked to ancestors. For many students who have few documents and records of their ancestors, family stories can provide important, and possibly the only, links to their ancestral past.

As a teacher educator who seeks to address issues of (in)equity and racial/social (in)justice in a university level classroom situated within a toxic political climate in which anti-immigrant sentiments and White supremacist racist ideology pervade the United States' political landscape, the first author faced inordinate challenges when teaching in a predominantly White institution (PWI) in a conservative state in the US. For those in similar situations who choose to plant themselves in the belly of the beast by teaching at an institution of higher education primarily attended by students from conservative, Christian, Southern, White families, the challenges of teaching preservice teachers about a critical multicultural perspective provide rich opportunities for existential musings and to seek out meaningful pedagogical approaches.

It would seem that the grueling and necessary slog of challenging White supremacist racist ideologies by engaging with preservice teachers is the work done "in the trenches," and the first author was both curious and uncertain as to how to approach the new assignment of teaching multicultural education, while also engaging with the few students of color who would also be in class. Leonardo (2013) points out that "like a fast-moving train maintains its trajectory without the application of force to the contrary, racism in education becomes indomitable unless it meets with active resistance" (p. 17). Ultimately, then, working at a PWI came to be viewed as a golden opportunity to shift the trajectory of racism's path by critically engaging with preservice teachers. It was an opportunity to develop a pedagogy of resistance. But how?

\section{Contextual Background of the Research}

\subsection{Critical Family History Projects}

After attending a session at the American Educational Research Association (AERA) meeting in which scholars shared how they had used Sleeter (2015) book entitled White Bread as a vehicle to support students to critically face their families' past, the first author decided to try this unique approach as a tool of interruption of racialized ideas, with the hope of creating deep cognitive dissonance. Using Sleeter's book as an exemplar to support students in conducting a Critical Family History (CFH), the assignment included a presentation, in which students were expected to articulate whether their ancestors (other than indigenous ancestors or those of African descent) were pushed or pulled to come to the U.S. due to political, economic, or religious reasons-exactly like current-day immigrants who are pushed or pulled by the intrigue of the myth of the United States. In this way, students whose ancestors immigrated to the U.S. could explore what was going on in their ancestors' lives that sparked them leave their lives and make the journey to the U.S.

The biggest conundrum was how students other than those who were of European descent would fare in this project. However, with the rise of White nationalism and White supremacist ideology and hate crimes, the urgency to face this crisis head-on by having the preservice teachers/students learn of their own family's history, while also learning from their classmates seemed compelling-for all students. Students' families' lives became the heart of the curriculum - with the goal to make this work transformational, rather than cosmetic - by seeking to make students feel uncomfortable intentionally (Case and Ngo 2017). Ohito (2016) explains this very concept in this way: “ . . discomfort as pedagogy cultivated White preservice teachers' openness to supporting each other in a learning community premised on political relationships as vessels for deepening critical consciousness about race, racism, and White supremacy" (p. 459). The notion is for the community of learners to grow together through being vulnerable about their discomfort and allowing that space to be the soil for inner growth. 
For the assignment, students' research into their families' history culminated in a book, video, or PowerPoint, which they presented to their classmates. While this approach seemed novel and a decolonizing way of learning, this project nonetheless had its challenges: what if a student were of indigenous or African descent and they had limited access to primary documents or information about their ancestors? What if the student had been in foster care or they were adopted? How would they deal with the challenges of such an assignment? Would/could this assignment create angst and emotional wounds for some students, and would that be fair to them, in order for the other students to gain important lessons and information? These questions continue unanswered, and yet, the decision was made to persevere and have students create critical family histories to gain insight into their ancestors' journeys and struggles and learn from and with each other. What would such an assignment teach and how could it create value?

A CFH begins with important questions on who, how, why, when, and where did my ancestors come to the U.S.? What were their stories, and what were the personal-political-social power struggles involved? For the first author, as a researcher on teacher education, this study began with this question: what meaning and value is created when college students engage in a $\mathrm{CFH}$ project, where questions are asked that had previously been left unasked and conveniently unanswered-possibly for generations? Simultaneously, it seemed important to engage in this research with a former student, believing that a de-colonizing approach to research requires collaborative efforts, rather than research that is one-sided with a scholar on one side providing insights and understandings of those being "studied." Instead, a relational and collaborative approach to research opens pathways to a decolonial view that involves shared research rather than the focused gaze of a scholar on others. It was for this reason that the first author asked her class of students of multicultural education if anyone would like to conduct research on the value of doing critical family histories. The only African American student in the class responded that she would, and so, the research journey began—with uncertainty about where this research would lead.

At the inception of the research, discussions focused on how this kind of assignment can create value in students' lives to challenge biases and deeply-rooted notions about themselves and others, but week after week, the student co-researcher found herself wanting to continue digging deeper and deeper into her own family's history. As it turned out, the class assignment to research her family's history had only served as the priming of the pump for her. She yearned to learn more and more with each new piece of information she found. Time and again, dialogues returned to some fascinating new piece of family history she uncovered and how the knowledge of that information served to shift an understanding of the U. S.'s past-particularly around the "peculiar institution" of enslaving people of African descent that has never been fully addressed, acknowledged, dealt with, or squarely faced by most contemporary Americans.

The initial motivation for this research stems from the first author's role as a teacher educator and the need for a robust and deep toolbox full of tools to both engage and interrupt students' ideas about systemic injustices and help them to develop a broader understanding of their privileges (or lack thereof), as well as an understanding of who maintains power and privileges at the expense of others. Where do university level students and their families fit into the complex web of our contemporary socio-cultural mosaic and what are their personal familial links to that web? This was the question that propelled this research and it was important to conduct this research with a former student in order to gain insight from a student's perspective.

\subsection{Research Questions}

In summary, then, this research consists of the following wonderings and questions:

(a) How does conducting critical family histories (CFH) serve to challenge preservice teachers and undergraduate students' understandings of their families and others, in order to expand their capacity for empathy for when they work with diverse students and people in the future?

(b) What can digging through layers of a family's history reveal? 
(c) How does a deeper understanding of one's family history from a critical perspective affect researchers and learners?

To answer these questions, this paper will use a multi-pronged approach and perspective: (1) provide substantive arguments to support an anti-racism pedagogy through the use of critical family histories; (2) present stories from an undergraduate student's findings about her family that transformed her understanding of herself, her family, and U.S. history; and (3) provide practical suggestions for those who wish to engage in conducting their own critical family histories.

An essential aspect of this project that unexpectedly emerged was that it ultimately resulted in developing "students as curriculum makers." This notion extends the concept of "teachers as curriculum makers," in which Connelly and Clandinin (1990) assert that "what emerges from this mutual relationship are new stories of teachers and learners as curriculum makers, stories that hold new possibilities for both researchers and teachers and for those who read their stories" (p. 12). This research pushes forward that very notion by suggesting that through students sharing their family stories, it is the students who become the curriculum makers. With students as the "drivers" of the curriculum, students' critical family histories became the heart of the curriculum in the course and served as real-life examples to illustrate the abstract concepts about critical multicultural education learned throughout the semester.

The critical family project used in this university level class, then, had an explicit purpose for all students, and specifically for students from conservative White rural families, which was this:

... it is precisely white shame and denial that must be acknowledged and dealt with in order to resist constructions and performances of whiteness that permeate regimes. In downplaying or forgetting the realities of racial violence that have conditioned white privilege in the Old South, white southerners assert their position as innocent people who are merely interested in knowing about their culture and preserving their heritage. Associations of whiteness with innocence permeate many white people's representations of ourselves. (Hall and Cuomo 1999, p. 34)

The seemingly formidable challenge for the first author was how to keep students engaged in their research, as well as their classmates' presentations, while simultaneously challenging students to think critically about their own and others' stories. While the goals were clear in wanting to encourage students to examine and dismantle notions of deeply internalized whiteness, especially if students planned to become teachers, the potential challenges inherent in such an assignment involved asking students to be vulnerable in front of their classmates and share aspects of their families and histories, often comfortably hidden away.

\subsection{Critical Family History Projects as Funds of Knowledge}

For elementary educators, the notion of "funds of knowledge" provides an excellent tool to expand teachers' awareness about and understanding of their school-age students, their families, and their cultures. Moll and Gonzalez (2004) summarize funds of knowledge as " ... an approach that presents both theory and methods for teachers to conceptualize diversity as an asset by addressing its substance, the varied ways people engage life, and the funds of knowledge these engagements produce" (p. 713). This focus on families and their histories as assets, rather than deficits, is a critical point for educators and learners. Moll (2015) further explains how important it is "to 'appropriate' or take possession of the funds of knowledge and other resources that exist in local households and communities to shape a pedagogy that both connects to students' experiences and engages them academically" (pp. 114-15). This is precisely what $\mathrm{CFH}$ accomplishes on the university level for professors, as well as learners. The missing link for university level teacher educators is how to bring in students' families' funds of knowledge into the classroom community. A CFH Project can be a vehicle to include funds of knowledge that college students bring with them into the classroom. In this way, each student's unique family's fund of knowledge could be honored and acknowledged—as an antidote to focusing 
exclusively on a Euro-dominant, heteronormative narrative; rather, portals to other ways of knowing and being in the world could be opened wide.

For scholars and students, the challenges of "truth-telling" about the institution of slavery continue to require pushback and resistance. For instance, nationally, the first U. S. museum devoted exclusively to the history and challenges of African-American people opened in Washington, DC in 2016. A museum committed to exposing the truth about lynching during the Jim Crow era, which documents people's names, opened in Alabama in 2018. As recently as 2015, a national news story in the U. S. highlighted a mother who found a reference to enslaved Africans as "workers" in her child's Texas textbook, which is yet another example of how the citizens of the United States still have not had a substantive national dialogue about slavery and its continued impact on people today, especially African Americans. For these reasons, the kind of research presented in this paper is urgently needed in order for the truth to continue to be told.

\subsection{Theoretical and Conceptual Framework}

This paper draws from the theoretical framework of critical race theory (CRT), as well as from the conceptual framework of Soka educational philosophy. Critical race theory (CRT) plays a key role in providing several theoretical concepts that undergird this research, since these ideas challenge Euro-dominant and Euro-normative narratives. By providing counter-narratives, CRT is a potent tool to challenge an oppressive hegemony and world-view. For Sleeter (2015), a central idea of critical family histories is for researchers to "locate their own families within the class structure, asking how family members came to be located where they were, analyzing their participation in the nation's economy and examining their vested interests in it" (p. 3). This approach provides a vehicle for students to both learn about their personal families' histories, while simultaneously connecting those histories with broader political-historical-systemic issues. The potency of such an approach is for students to shine bright lights on ignored, erased, hidden, or uncomfortable parts of the nexus of their lives by having their families' stories serve as counter-narratives to the dominant narratives that blanket U.S. curriculum on all levels.

CRT places race as a central theoretical component, which is why this theoretical framework is foundational for this research. According to Dixson and Rousseau (2005), CRT "positions race at the centre of analysis and reflects the recognition of racism as endemic to US society. It questions mainstream discourse centred on neutrality, objectivity, colour-blindness and merit. It insists on historical and contextual analyses" (p. 22). Ultimately, the theoretical ideas of CRT seek to support scholars and practitioners to end racial oppression, which completely aligns with the purpose of students conducting critical family histories.

Soka educational philosophy comes from Japan and is based on the ideas of a World War II educator and war-resister who died in prison, Tsunesaburo Makiguchi (Bethel 1994; Goulah and Gebert 2009). "Soka" is a Japanese term that means "to create value"; the current Soka educational philosophy, as applied in PK-12 schools in Asia and Brazil, originally comes from Makiguchi's ideas that have been further developed by the contemporary philosopher, peace activist and author, Daisaku Ikeda. Recognizing the significance of these ideas, Sonia Nieto (2012) finds Soka educational philosophy to be "a breath of fresh air in a field decaying from self-interest, money, and cynicism" (p. 156). While Soka schools are all secular, key ideas are based on Buddhist humanism, which considers the sanctity of all human life as a foundational idea (Ikeda 2010). Many educators around the globe who have studied Soka educational philosophy seek to apply essential principles to their classroom practices. Two key principles of Soka educational philosophy which provide theoretical underpinnings of this research are: (1) education for global citizenship and (2) the idea of the interrelatedness of all life. Each concept will be further explained below briefly.

Global citizenship education links academic subjects with students by guiding them to acknowledge how their lives are inextricably connected to people around the globe. Ikeda (2010) concisely expressed these ideas in a talk, "Education Toward Global Citizenship," when he spoke at 
at Columbia University's Teachers College in 1994. For Ikeda, qualities of global citizens include the capacity to have

- The wisdom to perceive the interconnectedness of all life and living;

- The courage not to fear or deny difference, but to respect and strive to understand people of different cultures and to grow from those encounters with them;

- The compassion to maintain an imaginative empathy that reaches beyond one's immediate surroundings and extends to those suffering in distant places. (pp. 112-13)

In the U. S., one way to begin this process is by helping students to recognize ways their own lives have direct connections to people around the world-beginning with their families' stories. A CFH can be an entrée for students to acknowledge ways they are directly linked to people quite possibly from a different class, culture, or background from their current situations.

Finally, Soka educational philosophy provides a theoretical framework based on the idea that all of life is interconnected. Ikeda (2010, Ikeda 2013) provides deeper insight into this point, which is from a speech given at Harvard in 1991:

all things are linked in an intricate web of causation and connection, and nothing, whether in the realm of human affairs or natural phenomena, can exist or occur solely of its own accord ... [because of] a level of interrelatedness that is uniquely dynamic, holistic and generated from within (p. 195)

Recognizing how all life is interconnected can shift an educator's recognition of the power of their work and the chosen curriculum. It is for this reason that this point is an important theoretical perspective linked to this research. By starting within their own family histories, while also learning about classmates' stories, students begin to recognize how deeply interconnected all people are. In this way, this theoretical concept supports the process by which students begin looking within themselves and ultimately recognize their connectedness with others.

\subsection{Critical Family Histories as a Tool of Transformative Pedagogy}

Scholars from various backgrounds recognize the potency of CFH as pedagogical tools of transformation that include deep introspection that accompanies historical research on one's family of origin. The scholar Chang (2019) writes that

if we are to actually start and sustain the organic groundwork of social change, with all of its tensions, let-downs, and contradictions, it is crucial to meet all stakeholders at eye- level, talk-story about where our families come from and where we wish to go, and be caring, reflexive, and intersectional as we develop our pedagogies and methodologies for change. (p. 167)

Over and over again, the ancient approach of telling stories from the past, linked with introspection, point to an impactful pedagogy—and methodology—that expands students' capacity for empathy.

\subsection{Methods}

The methodological approach for this qualitative research is narrative inquiry, which is dialogical, relational, and based on lived experiences of those included in the research. While the initial research question that pushed this research forward-questioning how conducting a CFH as a college-level project impacts students, the story that consistently emerged was of the untold and hidden stories of ancestors-gradually pieced together in such a way as to challenge views of the Euro-dominant version of U.S. history. This was because the stories that continued to press upwards came from the student digging further and further and discovering truths about her ancestors-lived realities of enslaved people and their descendants living through the Jim Crow era and the Civil Rights Movement. 
As a new instructor on the college level, the first author sought advice and support from the college's library, and through serendipity, discovered that the university had a staff member with a passion for genealogical research in the library. The librarian was invited to the class, and while he provided helpful information about resources to conduct this kind of research, his advice focused on the importance and value of stories. This advice "to focus on the stories" became central to the students' research in class, along with the more in-depth research at the heart of this paper. Below is a summary, in the librarian's words, of some of the stories he uncovered, which he shared to highlight the unequivocal importance of stories. This served to encourage students to find their own, thus linking their ancestors' lives and their own to history in ways they may have never considered:

Some researchers compile huge lists of thousands of relatives-with dates of births, deaths and marriages, but without any stories. These are as interesting as a phone book, and they don't provide any insight into people's personalities or a family's culture.

What is interesting are family histories-stories about your relatives; information on who they were, how they lived and why they behaved in certain ways.

One of my ancestor's cousins, Lucinda Boone, was married to Rev. John Berry Watson. Family tradition states Watson spoke out strongly from the pulpit about the slavery issue in 1864. Following is a newspaper account of the consequences, published a few years after the [Civil] war:

'Rev. John B. Watson (Methodist Protestant), a citizen of Hall County, than whom a more inoffensive, pious, loyal citizen never breathed the vital air, had his house searched and robbed seven or eight times by the rebels who threatened to take his life on first sight. He dare not sleep in his house at night, but had to lie in the woods day and night for several weeks to save his life. At length determined to seek the protection of the Federal army he started from home in the night and after traveling nine or ten nights through the woods on by-paths (for he dare not travel by day, for fear of being caught by the rebels) he at length arrived at Chattanooga, Tenn., where he had the protection of the Federal army. After a few months, becoming anxious to know how his family were doing in his absence, he started for home. He had proceeded little more than half the way when he was caught by a party of rebels in Cherokee county, who put an ox-chain round his neck and hung him on the limb of a tree.' Christian Cynosure, 14 November 1872

This story documents the brutality of war. It also illustrates that not all White Southerners supported the Confederacy.

Learning about family history helps researchers put their own lives in context. People muddle their way through confusing times, making difficult choices, and we all wear blinders. I tell students not to editorialize. Let the facts tell the story.

The methodology to conduct a CFH ideally includes accessing contemporary online tools, that the university's staff librarian shared. A key point of this research, that supports the advice of the university's librarian/genealogist, is to center the research on stories as the starting point and link those stories to historical events. Narratives are at the heart of this methodology.

\section{Alicia's Story}

This section of the paper is from Alicia's point of view, a student who continues to dig into her history and who increasingly questions choices her ancestors made or were forced to make. This emerged from Alicia's desire to more deeply understand the times in which her ancestors lived and the dilemmas facing them (her reflections are indented in the text). A shift in understanding her family's history has a profound effect on her, as articulated in her story. 


\subsection{Initial Concerns}

Alicia was the very first student to volunteer to do her CFH project presentation to the class, after the class heard a presentation by the librarian about approaches and resources, along with being provided sufficient time to prepare. She was the only African American student in the class, and there had been a class discussion in which the class considered the varying amounts of resources available to all students to discover information about their ancestors. For example, some students may have been raised in the foster care system or adopted, or come from a migrant family with little documentary proof of ancestral ties. Alicia described her initial feelings:

The family history project in this class wasn't something that I was confident about in the beginning. I, an African American young woman, only know that my ancestors were slaves, and a few names in the family. I had no idea if my family had any stories or documentation of their lives because their whole humanity was stripped away from them. I had this feeling in my gut that everyone would expect this certain story from me. It kind of went like "Hi, my name is AW and this is my family history project. My ancestors are from Africa and were forced into slavery for centuries, now here is my great-grandmother Ezola". I skipped generations of my bloodline in my ideal story. I didn't know where to start or who to go to because I had this idea that already convinced me that this wouldn't go well for me morally. How can I stand in front of a group of people-a group of people whose race is majority white? A group of people that don't look like me, Black.

Alicia's initial reactions to this assignment precisely mirrored concerns about her doing this kind of research, since she is a young woman of color, along with others who might not have their lineage on file with the Census Bureau or the Mormon Church. Would this kind of CFH project cause further anxiety for students who may have been systematically and structurally marginalized because of the color of their skin, economic situation, religion, birth circumstances and/or immigration status of their family? It was critical that this research did not have the unintended consequence that the students of European descent would learn about the U. S.'s past at the expense of students who didn't neatly fit into a Euro-dominant, heteronormative, Christian background. For the instructor, it became clear that a narrow way of seeing the world influenced by a Euro-dominant, White perspective actually served as a blinder to the immense potential of this project to support each and every student as they uncovered their family's past, especially Alicia.

\subsection{Realization that an Ancestor Was an Enslaved Woman Forced to be a Concubine}

Alicia continued to seek ancestors from elders in her family. She describes what happened next:

When Cousin Ben picked up the phone, we exchanged our hellos and then he told me to grab a pen and a notebook. He gave me the lineage of the family and then I figured out that he traced our ancestors back to when my 4th Great Grandmother, Marie Louise, was forced to America from Africa. I felt that what he was giving me was so generic because all I have is names and places, but no stories. I asked Cousin Ben what was the life of Marie Louise and our other ancestors who were enslaved. He paused for a minute and said 'I don't know if it'll be appropriate for your project'. I asked him why and then he stammered and asked

'How old are you again?'

'I'm 19, I'm in college right now,' I responded.

He then expressed how he thought I was in middle school and then he started all over and began to link stories with these names and places. I asked him again what was the life of Marie Louise and our other ancestors who were enslaved and he said that they were concubines. I didn't know what that meant so I looked it up as were on the phone. Reading 
what it is made my stomach turn because as I read it, it reminded me of the film "The Birth of A Nation." In the film, Gabrielle Union played the character of a Black women enslaved and in one scene she was forced to be a concubine. It was a heart wrenching scene and it's all I can see in my mind when I think of my ancestors being concubines on top of being enslaved.

As a college student, Alicia's cousin Ben felt that she was old enough to learn the painful truth about one of her ancestors. When she got to the part of her presentation where she explained that one of her ancestors had been a concubine to the man who was the slave owner, the class was stopped to be sure everyone knew exactly what a concubine was and what it meant in that context. This was done to ensure that the class was very clear: when Alicia shared that her ancestor was a concubine, she was letting us know that the man who legally owned her ancestors in order for them to work as free labor also made extra money by forcing one of her ancestors to have sex with other men. The word "rape" was invoked, as this was clearly sex without consent.

The class became appropriately quiet and uncomfortable. Such facts were never once mentioned in history books they had read from their high school days, but with Alicia's critical family history as the heart of the curriculum that day, students learned an incontrovertible truth they would probably never forget. It was part of our collective history often overlooked, ignored, and forgotten-in an attempt to erase many of the facts of the United States' past.

As Alicia reflected on that moment, she realized that

Learning that my ancestors were concubines made me feel numb. I didn't know how to feel and I didn't know what to think. I couldn't process it and even till this day it is a lot to process. I wasn't sure if this was something I wanted to put into the project because I couldn't wrap my head around this information. Why am I going to stand in front of people and share something so personal and so new, well at least to me?

Earlier in the course, students were shown the familial genogram of George Washington's family, using a genetic map to show how much rape had occurred within the U.S.'s "Founding Father's" family; again, the term "rape" was used, indicating there is no way for consensual sex to occur when one person is enslaved. The example Alicia gave, however, made these abstract distant "facts" and "concepts" very real. This was part of their classmate's family history. Like Alicia, most of her classmates had expressions of "numbness" on their faces as they took in Alicia's story of one of her enslaved ancestors.

As the presentations continued over several classes, it became clear that Alicia's CFH was one in the kaleidoscope of stories students shared; however, that initial shock and feeling of numbness of acknowledging a part of history so closely connected to us in that classroom was mentioned at other times in the semester. All of the students' critical family histories were also filled with surprising and shocking information, but for the scope of this paper, the emphasis is on Alicia and how this research impacted her. As an example, one student who had a mixed heritage of White and Mexican parents discovered some of his family's indigenous roots, which really surprised him and his classmates. While none of us who read and study history should be surprised by any of this, as students realized that their lives embodied historical encounters, it became evident that a shift occurred in their understanding of themselves, each other, and history.

\subsection{Complexities of the Colorline: Passing for White}

As this research continued, Alicia sought to find more answers about her family history by looking deeper and deeper into her family's past. One of the most shocking findings for her revealed the complexities of choices her ancestors were forced to face, based on if they could pass as White. Her findings revealed that ancestors in her family dealt with the colorline in very different ways. The first surprising discovery she made was that the man who owned many of her ancestors was a man named Louis Fontenot, a man of African ancestry who passed as White and became a slave owner. 
Someone more recent in her family ancestry, a woman named Marcelite, on the other hand, could have passed for White and made the conscious choice not to.

As Alicia reflected on the choices her ancestors made, she struggled to understand the historical and personal circumstances that drove them to live as they did. Alicia reflected:

Louis Fontenot was a man of color but I'm not too sure if it was known he was a man of color while he was alive. He could've hidden it. His dad could've hidden it from the rest of the family to keep his son in the family. But why would he keep Louis? Usually when the masters would impregnate a slave, they disown the child and never acknowledge their existence. Why would he give Louis this luxury of being a white man? He gave him his property which made him so much money. I should keep looking into my family, but Louis has been taking my interest over the past couple of days. Yes, Marcelite chose not to pass and that interests me but I keep asking myself this: 'Is it weird that I fall more into figuring out who Louis was?' Their eras are apart, and America was way different when the two lived. But to know that a man of color whose Dad was a white man inherited his estate and maintained so much power during slavery is taking over my interest. It's unbelievable. Louise Fontenot is a man that I have come to realize I will never truly understand. Every time I figure something out about him, I begin to ask myself why. Why do I want to know about the man who owned my family? Maybe I want to figure out specifically how my ancestors lived.

In discussions about the research, these two ancestors continued to play a dominant role. Alicia shared that she heard that Marcelite's brothers, who were White and shared the same father as Marcelite, whose mother was African American and who could have passed as White but chose not to, would go and visit Marcelite; however, they would always stay outside near the porch-never entering her home. A recognition that the lived realities of Alicia's ancestors, whose social and familial relationships were directly tied to the social and racial mores of the day, served as a catapult to consider another perspective on U.S. history, never considered before. Possibly these ideas were part of a prior history lesson, but to realize this was the experience of Alicia's ancestor was transformative.

\subsection{The Numbing Realization of Facing an Ancestor's Lynching}

Towards the end of this research, Alicia uncovered yet another narrative that links her and her family to the lynching death of an ancestor. She recounts both the story and her feelings about it:

As I gathered more and more information, I still noticed that there were a few holes that needed to be filled in. Cousin Ben gave me the puzzle pieces, helped me put some of them together, but there was information I knew from stories that my Grandmother told me. Learning about my history gave me a personal connection to each person that I learned about. These weren't just stories; these stories have a personal connection to me. This is different than learning about Harriet Tubman or Frederick Douglas. It's different because these people are my family, my blood, and it didn't happen that long ago.

One piece that I put together was about my 3rd great grandmother Hyacinthe. Hyacinthe was the daughter of Marie Louise and was born into slavery but lived to be 'free.' My mother told me before that nobody really messed with my Grandmother's family because my 2nd Great Grandfather, Aurelien II, had hate for white men. I asked her why and she said because he found his mom hanging. She was lynched when he was a young boy. I knew this story and as I started to connect some of the pieces to the puzzle, I realized that the woman who was Aurelien's mother, was Hyacinthe.

This gave me chills, and also made me feel numb. I don't even care to know why she was lynched, because there's no reason for her murder. Without even digging I already know that 
her murderer or murderers got away; it was because she was black, and she was left alone to die. America's racist history is so heavily engraved in this country today that I didn't even have the stomach to dig further into her death, because again I already know that there is nothing to dig for. No records will be there, no memorial will be there, no apologies, no remorse, nothing.

I never knew Hyacinthe, but when I connected the dots, I instantly felt like I knew her, I felt a huge range of emotions that was a little aggravating because the oppression isn't just history. I didn't live in the times of slavery, or Black Codes, or Jim Crow, and neither did the white people in my class, but if I can feel what I felt and cry in the slightest bit over Hyacinthe whom I never met, why is it that my white counterparts still have the same ideology that we (Black people) have to get over these times? I personally can't get over the centuries of oppression because there has been no remorse for it.

\section{Discussion}

This section focuses on the instructor's challenges with doing a CFH project, in order to provide as expansive a learning experience as possible to support students in developing a critical multicultural lens. The stories that poured out of Alicia's life as she continued to dig and ask more probing questions were transformative. While much of this research began with a question of the value of having students conduct critical family histories as portals of understanding their own lives and others-especially for those students who may be marginalized in some way, the findings were unexpected. The recognition and understanding of the lived realities of descendants of enslaved Africans whose blood intermingled with the very people who mistreated them, abused them, took advantage of them, enslaved them, and who bore children with them was no longer an abstract historical fact or horrific scene from a Hollywood movie. Rather, it was the lived experience of a student's ancestors and part of her heretofore unknown heritage. This research journey took surprising twists and turns. In the initial stages of research, when a question is proposed with wonder and curiosity, uncertainty abounds as to the answers that will emerge. The anticipation of finding answers propel researchers forward, and such was the case with this research, as the researchers sought to find meaning and value in college students conducting CFHs.

Scholars in the field of narrative inquiry (Connelly and Clandinin 1990; Craig et al. 2017) suggest that as stories are re-storied, the stories change us all as we interact with narratives we read. Through engaging in the research process that included uncovering and giving form to hidden narratives almost lost to Alicia and those of us who read about them, we see how dynamic, collaborative, and relational narrative inquiry can be. As a collaborator and co-researcher, Alicia birthed a "new story" from her ancestors' lives and as these stories are further re-storied through our interactions with them, we reconstruct and re-story our understanding of the lives and experiences of enslaved Africans we possibly never considered. For Alicia, the experience of discovering stories never before imagined about the unthinkable dilemmas and choices faced by so many people of African descent forever changed our understanding of this long, harsh chapter of U.S. history, told to all of us in sanitized snippets that sterilize and strip the fullness of experiences as facts and figures.

\section{Concluding Thoughts}

Ultimately, then, this research revealed the potency of critical family history projects on the university level as a tool for anti-racism curriculum development. Sleeter's insight, which proved to be true for these researchers on this journey of discovery together, was the surprising realization about embodied history. Sleeter (2008) writes:

I carry a history and legacy of not only European American immigration, but also of Appalachia, of slave ownership, of African Americans passing as White and leaving family behind, and of Jim Crow. I recovered lost memories of blurred racial boundaries and 
reinvented origins, lost narratives of having both perpetrated and also having been victimized by racism. What I have gained from this research is a broader sense of who 'my' people are, what my legacy is, and responsibilities and debts I have inherited. The challenge facing me how is not to rewrite history, but to reinterpret the present and my position in it in relationship to history. (p. 121)

The versions of U.S. history never before considered by these researchers—of slave owners forcing a college student's ancestors into being a concubine and having sex so the slave-owner could make extra money; of one of her ancestors being of African descent, but passing as a slave owner and being both a victim and perpetrator of slavery; of knowing that an ancestor had been lynched and left to die in front of her young son; and of an ancestor who could have passed as White, but who intentionally chose not to-all had a palpable effect on us as researchers because history no longer consisted of distant dates, figures and contested versions of the past. History had become an embodied reality that could not be overlooked or glossed over. The more Alicia discovered, the more apparent it became we shared a vast and collective ignorance about what really happened to so many enslaved Africans.

The feeling of being lied to, misled, and duped by teachers and authors of history books was unsettling, but this new-found knowledge served to propel the researchers to want to continue to seek out, find, and put into action approaches to dismantle a systemically cruel and unjust system that continues to impact all of us today. Alicia's cousin was cautious and uncertain about sharing some of her family's secrets with her, because he was not close to her and wanted to be sure she was old enough to handle this kind of information.

This points to another reason that this kind of project is so important for college students. Most families believe they are protecting their children by hiding family secrets from them, and oftentimes, those secrets remain hidden. While this very issue warrants further discussion beyond the scope of this article, we believe that this hidden, but deeply felt, knowledge is buried viscerally. While the conscious mind may not know details and facts, visceral knowledge senses truths before they become conscious. For this reason, the potency of this kind of historical family research can serve to guide people to a deeper understanding of their experiences, along with those of their ancestors, which leads to healing from hidden internal lacerations unable to wholly and fully heal. Over the course of doing this research, it became unquestionably clear that conducting a critical family history project can be a transformative pedagogical process to challenge and dismantle racism.

Author Contributions: Conceptualization, V.M.; methodology, V.M. \& W.P.; software, NA; validation, V.M., A.W. \& W.P.; formal analysis, V.M. \& A.W.; investigation, V.M. \& A.W.; resources, V.M. \& A.W.; data curation, V.M.; writing—original draft preparation, V.M.; writing—review and editing, V.M. \& A.W.; visualization, V.M.; supervision, V.M.; project administration, V.M. All authors have read and agreed to the published version of the manuscript.

Funding: This research received no external funding.

Conflicts of Interest: The authors declare no conflict of interest.

\section{References}

Bethel, Dayle M. 1994. Makiguchi the Value Creator: Revolutionary Japanese Educator and Founder of Soka Gakkai, 1st ed. New York: Weatherhill. First published 1973.

Case, Alissa, and Bic Ngo. 2017. Do we have to call it that? The response of neoliberal multiculturalism to college antiracism efforts. Multicultural Perspectives 19: 215-22. [CrossRef]

Chang, Benjamin B. 2019. Two more takes on the critical: Intersectional and interdisciplinary scholarship grounded in family histories and the Asia-Pacific. Curriculum Inquiry 49: 156-72. [CrossRef]

Connelly, F. Michael, and D. Jean Clandinin. 1990. Stories of experience and narrative inquiry. Educational Researcher 19: 2-14. [CrossRef]

Craig, Cheryl J., JeongAe You, and Suhak Oh. 2017. Pedagogy through the pearl metaphor: Teaching as a process of ongoing refinement. Journal of Curriculum Studies 49: 757-81. [CrossRef] 
Dixson, Adrienne. D., and Celia K. Rousseau. 2005. And we are still not saved: Critical Race Theory in education ten years later. Race Ethnicity and Education 8: 7-27. [CrossRef]

Goulah, Jason, and Andrew Gebert. 2009. Tsunesaburo Makiguchi: Introduction to the man, his ideas, and the special issue. Educational Studies 45: 115-32. [CrossRef]

Hall, Kim Q., and Chris J. Cuomo, eds. 1999. Whiteness: Feminist Philosophical Reflections. Lanham: Rowman \& Littlefield Publishers, Inc.

Ikeda, Daisaku. 2010. Soka Education: For the Happiness of the Individual. Santa Monica: Middleway Press.

Ikeda, Daisaku. 2013. A New Humanism: The University Addresses of Daisaku Ikeda. New York: I. B. Taurus. First published 2010.

Leonardo, Zeus. 2013. Race Frameworks: A Multidimensional Theory of Racism and Education. New York: Teachers College Press.

Moll, Luis. 2015. Tapping into the 'hidden' home and community resources of students. Kappa Delta Pi Record 51: 114-17. [CrossRef]

Moll, Luis C., and Norma Gonzalez. 2004. Engaging life: A funds-of-knowledge approach to multicultural education. In Handbook of Research on Multicultural Education, 2nd ed. Edited by James A. Banks and Cherry A McGee A. M. Banks. New York: Jossey-Bass, pp. 699-715.

Nieto, Sonia. 2012. Review of Soka education: For the happiness of the individual (Rev. ed.). Critical Inquiry in Language Studies 9: 152-56. [CrossRef]

Ohito, Esther O. 2016. Making the emperor's new clothes visible in anti-racist teacher education: Enacting a pedagogy of discomfort with White preservice teachers. Equity E Excellence in Education 49: 454-67. [CrossRef]

Sleeter, Christine. 2008. Critical family history, identity, and historical memory. Educational Studies: A Journal of the American Educational Studies Association 43: 114-24. [CrossRef]

Sleeter, Christine. 2015. White Bread: Weaving Cultural Past into the Present. Rotterdam: Sense Publishers.

(C) 2020 by the authors. Licensee MDPI, Basel, Switzerland. This article is an open access article distributed under the terms and conditions of the Creative Commons Attribution (CC BY) license (http://creativecommons.org/licenses/by/4.0/). 